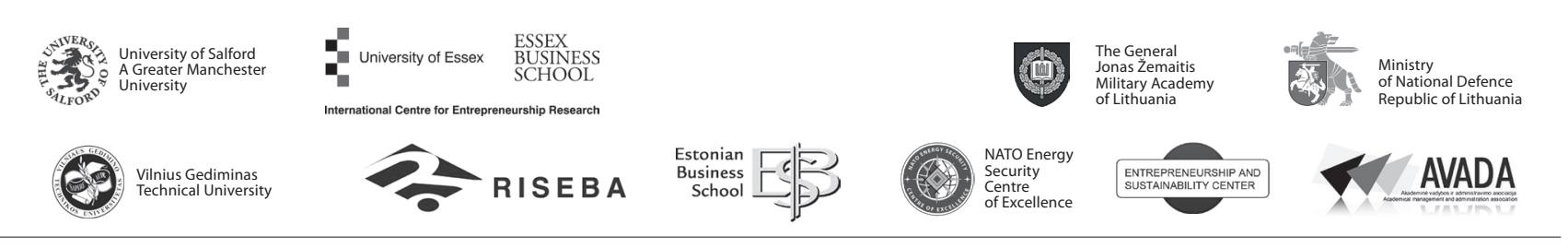

JOURNAL OF SECURITY AND SUSTAINABILITY ISSUES

ISSN 2029-7017 print/ISSN 2029-7025 online

2018 September Volume 8 Number 1

https://doi.org/10.9770/jssi.2018.8.1(4)

\title{
PATH TOWARDS NATIONAL SECURITY IN THE EUROPEAN UNION: GENESIS AND FURTHER DEVELOPMENT PROCESSES
}

\author{
Roman Volodymyrovych Shapoval ${ }^{1^{*}}$, Vasyl Yakovych Nastyuk $^{2}$, \\ Olha Ihorivna Bezpalova ${ }^{3}$, Nadiia Petrivna Khrystynchenko ${ }^{4}$ \\ ${ }^{1,2,4}$ Yaroslav Mudryi National Law University, Dynamivska St. 4, Kharkiv 61000, Ukraine, \\ E-mail:romanshap882@gmail.com
}

Received 15 December 2017; accepted 20 June 2018

\begin{abstract}
The article reviews standards of state policies in terms of the national security of the European Union countries. The authors provide a comprehensive analysis of the theory and practice of providing national security in the EU countries. In addition to that, the article provides for a deep analysis of the major methodological approaches in regards to establishing national security in the EU. The authors make a systematic review of the development and implementation of the EU security doctrines. The aim of this research article is to analyze the development of the idea of developing a European defense policy to find an effective way of incorporating our state into European security structures. Also, the research question may be posed as discussion on the way the national security is guaranteed in the EU countries. The novelty of the study is in the way how the past, current and future national security setup is implemented in the EU countries and what may the ways of its development. Materials and methods used in studying this problem, researches and publications of such domestic and foreign researchers were used. At the same time, processes of global and European security need constant analysis and study. The results showed that the problem of the formation of the European security and defense system that emerged shortly after the end of the Second World War prompted European countries to work more closely together, particularly in the defense sector. After the Cold War and the emergence of new challenges for stability on the continent, the EU has embarked on a path towards greater consolidation and greater awareness of own defense and security interests. Conclusion of the article is that an analysis of the approaches to the national security in the EU convincingly demonstrates that the level of security depends on many factors. The successful provision of national security strategy and approach depends on the sustainability and strength of their national economies. Only a strong economy allows successfully defending national interests in growing global competition and world economic disparities. Therefore, a country shall not only develop a national security concept, relying on world experience, but, above all, to reform its domestic and foreign policies with a view to protecting all actors.
\end{abstract}

Keywords: administrative support; legal support; national security; threat, European Union

Reference to this paper should be made as follows: Shapoval, R.V..; Nastyuk, V.Y.; Bezpalova, O.I.; Khrystynchenko, N. P. 2018. Path towards national security in the European Union: genesis and further, Journal of Security and Sustainability Issues 8(1): 45-54.

https://doi.org/10.9770/jssi.2018.8.1(4)

JEL Classifications: K1, K19

\section{Introduction}

The situation in the world and its main regions is formed under the influence of an exceptionally complex and dynamic process, which is based on the globalization of the world economy and the related revision of the whole system of international relations. In view of the continued desire of individual countries, peoples, political, religious and other groups, as well as individuals, to achieve their goals by any means, it has been further expanded, supplemented by new, previously considered potential threats (Fabuš 2017; Kordík, Kurilovská 
2017; Shvetsova et al. 2018; Kunitsyna et al. 2018; Kuril 2018; Limba et al. 2018; Tvaronavičienè 2018; Ohotina et al. 2018; Plèta et al. 2018). Recently, there are relatively new sources of external threats in the form of international terrorism and organized crime, drug trafficking, smuggling of weapons and military equipment, the danger of environmental disasters that require adequate responses (Šišulák 2017; Petrenko et al. 2017; Todorov et al. 2018; Njaramba et al. 2018; Lietuvnikè et al. 2018; Zahars, Stivrenieks 2018; Matvejevs 2018). The potential for conflict is growing due to the widening gap between rich and poor countries, political and religious extremism, aggressive nationalism, separatism and territorial claims, increased religious intolerance and xenophobia, high levels of terrorist activity and transnational organized crime, proliferation of weapons of mass destruction and uncontrolled proliferation materials and technologies that can be used to produce such weapons. There is a clear tendency to increase the vulnerability of all members of the international community in the face of a variety of challenges and threats, the range and severity of which are evolving, mutating and acquiring a transboundary character. As Wark (2005) wrote, "The threat of security is [...] security itself". In his work "Theory of World Security", K. Booth (2007) puts forward the idea of creating a world security system that transcends national boundaries and rejects the "instinctive animal struggle for survival": "The idea of world security is synonymous with freedom of individuals and groups that is compatible with the rational freedom of others, and universal moral equality compatible with justified pragmatic inequalities". World security will have to be based on a cosmopolitan democracy, which, in Booth's (2007) view, "can never be achieved through wars and revolutions, because such a new world order does not allow such means". Thus, the article aims to analyze the development of the idea of developing a European defense policy in terms of the attempt of the European Union to move towards greater consolidation and greater awareness of the power of interests in the areas of defense policy and security.

\section{Materials and method}

In the field of studying European security, critical security studies are conducted. The term of "critical (or non-traditional) studies" refers to a particular area in the field of security research, which differs from the traditional realistic approach in which the central role in ensuring security is assigned to the state. Critical studies focuses on economic, environmental and social security. The main thinkers of critical research are the Welsh, Copenhagen and Paris schools. Each of these schools has its own special approaches to the conceptualization of security.

The Welsh School is developing within the so-called Emancipatory theory. This current takes its origins in the Frankfurt School, whose prominent representatives are T. Adorno, J. Habermas (Singh, 2017). This theory was first put forward by K. Booth in the early 1990s. They advocate a universal security system in which the individual, not the states and nations, plays a central role. The second trend in non-traditional doctrines is the securitization theory, which is developing within the framework of the Copenhagen school. It includes such scientists as B. Buzan, O. Waever and J. Wilde. The theory is based on the idea that in international relations something becomes an object of urgent policy not because it represents a danger, but because an influential actor proclaims it as a serious threat. But securitization exists not only simply due to its popularization by the actor, but only after the audience perceives it. By accepting and legitimizing society, the actor can take extraordinary measures and "legitimize the breaking of rules" (Buzan, Waever, \& Wilde, 1998). The third direction of critical research is the "insecuritization theory" (Balzacq, 2010), developed by the specialists of the Paris School - M. Foucault and P. Bourdieu. Supporters of the theory (in particular D. Bigo) argue that "security" is what is done to it, that is, how safety is practiced. In this theory, security is not understood as an "anthropological necessity" (Burgess, 2010)(as in the emancipation theory) or as an act of public speaking (as in securitization theory) but rather perceived as a process of "securitization or insecure of borders, identities and notions of order" (Bigo, 2000). As Bigo writes: "Security - in any case not a reflection of the increasing threats in the modern era - it is the decrease in the level of acceptability of the other; it is an attempt at insecurities the everyday lives of professionals and the strengthening of political potential for action" (Bigo, The Mobius Ribbon of Internal and External Security(ies), 2001). Paris school theorists question the understanding of the security of the Copenhagen school, arguing that securitization is not the result of a successful public act, but everyday bureaucratic decisions, the use of technology and the Weberian practice of rationalization (Ritzer, 2017). 
Among the studies, one can also mention the work of J. Coelmont, a member of the Belgian Royal Institute of International Affairs and the European Military Committee, entitled "A European Global Security Strategy: Offering Seven-League Boots to Become a Global Actor".

\section{Discussion}

\section{Institutional mechanism of joint policy and security policy in the $E U$}

The institutional mechanism of the European Union's CFSP, which has evolved and improved over a long period of time, has been shaped quite clearly today. Functions in the field of the CFSP are assigned, to a greater or lesser extent, as the main institutions of the EU, and a whole system of special bodies for the implementation of the relevant policy of the European Union has been created. The Article 24 of the EU Treaty stipulates that the rules and procedures of the common foreign and security policy of the EU are defined and implemented by the European Council and the Council of the EU, which adopt resolutions unanimously, unless otherwise provided by the Treaties. The European Council, incorporated by the Lisbon treaties into the system of the main institutions of the European Union, according to Art. 26 of the Treaty on the European Union, reveals the strategic interests of the Union, sets goals and defines the general directions of the common foreign and security policy, including those with defense implications. And for this purpose, she makes the necessary decisions. The decisions of the European Council on the strategic interests and objectives of the Union concern the CFSP and other areas of Union foreign policy. At the same time, such decisions may concern the Union's relations with a particular country or region or provide a thematic approach. They define the term and means to be provided by the Union and the Member States. The European Council acts unanimously on the recommendation of the EU Council, adopted in accordance with the conditions for each sphere (Article 22 of the Treaty on the European Union). If the intergovernmental situation so requires, the President of the European Council convenes its extraordinary meeting to determine the strategic directions of the Union's policy in the light of such development. States consult each other within the framework of the European Council and the Council of the EU on any matter of foreign policy and security policy of mutual interest with a view to defining a common approach. That is, before carrying out any action on the international scene or assuming any obligation that could affect the interests of the Union; each Member State should consult other Member States within the framework of the European Council or the Council of the EU (Article 32 of the Treaty on the European Union). That is, it is not about the right but about the obligation to conduct such consultations. And it is precisely, as stated in this article of the Treaty, that, by converging their actions, Member States provide the Union with the ability to defend its interests and values in the international arena, while demonstrating mutual solidarity. The President of the European Council also plays a role in the European Union's CFSP. In particular, according to Part 6 of Article 15 of the Treaty on European Union, the President of the European Council, at his own level and in his status, represents the Union in the external affairs of the CFSP, without prejudice to the powers of the High Representative for Foreign Affairs and Security Policy. The Council of the European Union (composed of the Ministers of Foreign Affairs of the Member States), together with the European Council, defines and implements the EU's activities in the field of CFSP. Hence, according to part 3 of the Article 26 of the Treaty on the EU, the EU Council is developing a common foreign and security policy and adopts the decisions necessary for its definition and implementation on the basis of general directions and strategic decisions established by the European Council.

Thus, when the international situation requires operational action by the Union, the Council of the EU makes appropriate decisions. They define their goals, limits, means, which must be made available to the Union, and, if necessary, their duration and conditions of implementation. The Council adopts its decisions defining the position of the Union on specific issues of a geographical or thematic nature, and Member States, in turn, should ensure the consistency of their national policies with the positions of the Union (Articles 28 and 29 of the Treaty on the European Union). (On the special feature of legal acts in the field of CFSP, in particular those adopted by the European Council and the EU Council, see below). In turn, Article 30 of the Treaty on EU stipulates that, for the consideration of the Council of the EU, any questions, initiatives or proposals relating to the CFSP, such as each Member State, and the High Representative of the Union for Foreign Affairs and Security Policy, both on their own and on support from the EU Commission. In this case, in cases requiring a 
speedy solution, the High Representative, on his own initiative or at the request of a Member State, convenes an extraordinary meeting of the Council for 48 hours, or in case of absolute necessity, within a shorter period of time. And in important cases, on the proposal of the High Representative of the Union for Foreign Affairs and Security Policy, the EU Council may appoint a special representative, which she gives a mandate in relation to certain political issues (Article 33 of the Treaty on the European Union). In addition, the Council of the EU can conclude international CFSP agreements with other states or international organizations in accordance with the general rules for concluding such agreements in the field of external relations of the EU. The Council of the EU should also decide on the establishment of rules for the protection of individuals with regard to the processing of personal data by Member States when carrying out their activities in the field of the CFSP (Article 39 of the Treaty on the European Union).

The Treaty of Amsterdam introduced the post of High Representative of the Union for Foreign Affairs and Security Policy, which was performed by the Secretary General of the Council of the EU, and was given wider powers after the entry into force of the Lisbon treaties. For the first time, the post of High Representative in 1999 was occupied by J. Solana, who, thanks to his personal qualities and experience at the post of NATO leader (which respectively affected the intensification of the military component of the EU), was able to give the CFSP a special status commensurate with the other pillars of the European Union. According to Article 18 of the Treaty on the European Union, the High Representative of the Union for Foreign Affairs and Security Policy shall be appointed by the European Council, acting by a qualified majority, in agreement with the Chairman of the Commission. High Representative directly implements the foreign policy and security policy of the Union and contributes to the development of this policy, which he carries out as an authorized representative of the Council. He applies the same actions to a common security and defense policy. The High Representative chairs the EU Council on Foreign Relations and is one of the Vice-Chairmen of the Commission. It ensures the continuity of the Union's foreign policy. In the framework of the Commission, he is responsible for the duties that are common to this body in the field of external relations, and for coordination of other aspects of foreign policy of the Union (parts 3 and 4 of Article 18 of the Treaty on the European Union). Under the draft Treaty establishing a Constitution for Europe, the High Representative was to be called the EU Minister for Foreign Affairs, who emphasized the great ambitions of the authors of this draft treaty. The European External Action Service is assisted by the High Representative for Foreign Affairs and Security Policy in the exercise of his powers. According to Part 3 of Article 27 of the Treaty, this service cooperates with the diplomatic authorities of the Member States and includes officials of the competent services of the General Secretariat of the Council and the Commission, as well as staffed by the diplomatic authorities of the Member States. The organization and functioning of the European Foreign Policy Service was established by the EU Council Decision in May 2010 (EU Council Decision 2010/427). In this document, in particular Article 2 outlined the main tasks of the European External Action Service: support to the High Representative of the Union for Foreign Affairs and Security Policy in the implementation of his mandate in the field of CFSP and SABO, in his activities as Chairman of the EU Council on Foreign Affairs, as well as in his activities as deputy Chairman of the Commission. In addition, the European External Action Service should assist the President of the European Commission and the Commission as a whole, as well as European Parliament in the exercise of their functions in the field of external relations. Certain competences in the CFSP area are also endowed by the EU Commission and the European Parliament. Regarding the EU Commission, on the one hand, if one takes into account the provisions of a separate section of the EU Treaty on the CFSP, on the one hand, it is not mentioned very often, mainly with regard to the activities of the High Representative of the Union for Foreign Affairs and Security Policy, who at the same time is the vice chairman Commission, but, on the other hand, the Commission has more powers in the field of foreign policy through the prism of the provisions of the Treaty on the Functioning of the EU (negotiations on the conclusion of international treaties, representation of the EU in intergovernmental organizations, etc.).

In particular, in the context of the provisions relating to the CFSP, with the support of the Commission, the High Representative for Foreign Affairs and Security Policy of the Union and each Member State may submit to the Council of the EU any question pertaining to the CFSP and may transmit it to its consideration, respectively, of initiatives and proposals. In a way, the CFSP activities of the Commission relate to the implementation of the budget of the European Union in this area. According to the provisions of the EU Treaty, the competence 
of the European Parliament is also very limited in the CFSP. It is noted that the High Representative for Foreign Affairs and Security Policy regularly consults with the European Parliament on the main aspects and basic priorities of the CFSP and the WSIS and also informs him of the ways in which these policies are being developed. The High Representative will ensure that the European Parliament's opinion is properly taken into account and that its special representatives may be involved in informing the European Parliament (Article 36 of the Treaty on the European Union). The same article states that the European Parliament can ask questions or make recommendations to the Council and High Representative. Twice a year in the European Parliament, discussions should be organized on the progress made in the implementation of the common foreign and security policy, including the common security and defense policy. The European Parliament also has a certain impact on the CFSP through the control of the EU budget (since part of the expenditure on the CFSP is financed from the EU budget).The Lisbon treaties have largely limited the jurisdiction of the European Union Court in the field of CFSP, in comparison with other areas of EU competence. According to Article 24 of the Treaty on the European Union, the Court has no jurisdiction over the provisions relating to the CFSP, with the exception of jurisdiction over compliance with Article 40 of this Treaty and control over the legality of certain decisions provided for in the second paragraph of Article 275 of the Treaty on the Functioning of the EU. In the first case, it is a matter of the fact that the implementation of the common foreign and security policy of the EU cannot influence the application of procedures and limits of authority of institutions in other areas of EU competence, in particular, provided for in relevant articles 3-6 of the Treaty on the Functioning of the EU, and, conversely, the implementation of these policies does not affect the application of the procedures and respective powers of the institutions established for the exercise of the powers of the Union in the field of the CFSP (Article 40 of the Treaty on the European Union). With regard to the second case, the extension of the jurisdiction of the EU Court to the CFSP, then it has jurisdiction to take decisions on claims of individuals and legal entities, on the acts to which they are addressed or which are directly and directly related to them, and also with regard to acts which directly affect them, do not require implementation measures or which impose any restrictive measures against them (Articles 263, 275 of the Treaty on the European Union). In addition to these provisions of the Treaties, which clearly provide for the extension of the competence of the EU Court to the CFSP, it can also be argued that, according to Part 11 of Article 218 of the Treaty on the Functioning of the European Union relating to the conclusion of international agreements, a Member State, the European Parliament, the Council or the Commission may obtain a conclusion from the Court as to the conformity of the proposed agreement with the Treaties, in particular if this international agreement regulates matters relating to the CFSP. And in the case of a negative judgment of the Court, this agreement may only come into force when it is amended, or a revision of the contracts will be made. In the institutional framework of the CFSP, in addition to those mentioned above, there is still a number of special bodies that are set up to better achieve the goals and objectives of the European Union in this area.

The Committee on Political and Security Affairs, as a body in the field of the CFSP, under such a name, was included in the Treaty on European Union by the Treaty of Nice (formerly the Political Committee). It operates on the basis of Article 38 of the Treaty on the EU and Council Decision 2001/78 as of 22 January 2001. Functions and tasks of this body are very important. It is worth mentioning that the Committee of Permanent Representatives - COREPER, which consists of the ambassadors of the EU member states (COREPER II) and their deputies to the EU (COREPER I), plays a significant role in organizing the work of the Council of the EU. It is during the meetings of both committees that the Council of the EU prepares meetings, reaches agreement on the majority of normative acts, which are subsequently adopted by the Council, and coordinates the activities of numerous expert groups. It was these functions in the CFSP and was carried out by the Political Committee, which formally was an independent body. Similarly, the situation today is regulated by the Lisbon treaties. According to Article 38 of the Treaty on the European Union, the Committee on Policy and Security, without violating the requirements of Article 240 of the Treaty on the Functioning of the European Union (on the activities of a separate Committee of Permanent Representatives of the Governments of the Member States), monitors the international situation in the fields related to the CFSP, and contributes to the definition of policy through the preparation of conclusions for the Council at its request, at the request of the High Representative The Union for Foreign Affairs and Security Policy or on its own initiative. The Committee also monitors the process of implementing a coherent policy, while not reducing the authority of the High Representative. 
It is important that, within the framework of the CFSP, the Committee on Political and Security Affairs under the responsibility of the Council of the EU and the High Representative carries out political control and strategic management of the crisis management operations mentioned, in particular, Article 49 of this Treaty says that the Committee, in close and constant contact with the High Representative of the Union for Foreign Affairs and Security Policy under the leadership of the Council, ensures the coordination of civilian and military aspects of these missions (the so-called "Petersberg Missions"). In fact, with the aim and for the duration of such crisis management operations, the Council of the EU may authorize the Committee to take appropriate decisions regarding political control over the operation and its strategic direction. Meetings within the Committee are held at the level of high-level officials of the EU member states in the rank of ambassadors, mainly twice a week. The Committee established three subsidiary bodies: the Political and Military Groups, the Committee on Civil Aspects of Crisis Management, and the so-called "Nicolades Group", which prepares the Committee's meetings. The Strategic Planning and Early Warning Unit was created on the basis of the Declaration of the Sixth Amsterdam Treaty within the framework of the apparatus and led by the High Representative of the Union for Foreign Affairs and Security Policy, in particular, to coordinate the work of other Union institutions in shaping foreign policy. Its competence includes the creation of a network for obtaining and processing information from all EU structures and conducting an independent policy planning of possible strategic EU actions in the field of CFSP. Within the framework of the Committee on Political and Security Affairs, a Committee of European Correspondents, which includes designated staff of the Ministries of Foreign Affairs of the EU Member States, is responsible for the exchange of information between the Member States, the General Secretariat of the Council of the EU, the Commission and the diplomatic representations of the Member States.

The Military Committee and the Military Staff were established by Council Decision 2001/79 as of 22 January 2001 "On the Establishment of the European Union Military Committee" and "On the Establishment of a European Union Military Staff” for the management of the Rapid Reaction Force.

A number of auxiliary agencies have also been set up within the framework of the CFSP, which, in the main, contribute to the goals and objectives of the common security and defense policy. The Agency for Defense Capabilities, Research, Procurement and Arms Development (European Defense Agency) was established by Council Decision 2004/551 as of 12 July 2004. Article 42 of the Treaty on the European Union calls on the European Defense Agency one of the main tasks of the EU to improve the military capabilities of the Member States. To this end, it establishes operational requirements, promotes measures for their satisfaction, contributes to the identification and implementation of any measures that are useful for strengthening the industrial and technological base of the defense sector, participates in the development of a European policy on potentials and weapons, and helps the Council to assess degree of improvement of military potentials.

The European Union's satellite center, established by Council Decision 2001/55 as of 20 July 2004, has become an essential element of the development of a common EU security and defense policy, in particular, for monitoring crisis situations. In particular, the positive experience of its operation was noted during the promotion of EU operations in the Balkans and in joint activities with the United Nations. The EU Institute of Security Studies, established in accordance with the decision of the Council of the EU 2001/554 as of July 20, 2001, with a focus in Paris to conduct research, exchange scientific advances and prepare expert opinions for other EU institutions in the field of European security. The EU Operational Center operates in the EU Military Staff system and contributes to the EU's capabilities in planning and providing military operations. Lastly, it is important to note that the EU Council Decision 2004/197 as of 23 February 2004 established a special mechanism for the management of the use of common European Union operations that have an impact on military and defense issues, i.e. Athena. This mechanism is designed to manage funds to cover common costs for relevant military or defense missions. Athena is used within the framework of a special committee, which includes representatives of the states that make financial contributions for the implementation of this operation. Thus, despite the rather complicated institutional framework of the CFSP, it can be argued that the European Council, the Council of the European Union and the High Representative of the Union for Foreign Affairs and Security Policy with the European External Action Service have the main significance in the process of functioning and decisionmaking in this area. 


\section{Globalization and its meaning for the EU}

The European Union, which today brings together advanced Western democracies, is a well-established entity that objectively attracts the states of Eastern and Southeastern Europe, which consciously have chosen a democratic direction for their development and wish to occupy a worthy place in the European economic space. The process of strengthening European integration as an independent factor is of particular importance for states in the East of the continent and the surrounding regions whose countries seek to deepen their ties with the European Union. According to E. Nolte, the driving force behind EU enlargement is nothing more than the ideological commitment of many Europeans to the concept of an enlargement of the Union, if it takes place at a minimal cost and leaves undemocratic and authoritarian beyond the bounds of the country's enlargement (Nolte, MacLehose, \& McKee, 2004). The effects of globalization can also be attributed to the leveling of the state's leading position in ensuring the security of the society, especially internal security. Thus, the security object is expanding, justifying, on the one hand, EU involvement in the affairs of other unstable regions, such as the Middle East, Africa, and Central Asia. On the other hand, the priority of the individual over the state prepares a fertile platform for implementing projects to create a world government that cares about the safety of all people without exception on the planet.

\section{Research in the direction of European security}

The European Security Doctrine was formed relatively recently, and its creation was the result of both internal, related to the logic of EU development and external factors. One of the most important think tanks in Europe in the field of global security is the European Union Institute for Security Studies. The European Council on Foreign Relations is another influential research center in the field of security. In 2010, the Council published the article named "The illusion of order and the formation of a multipolar Europe". It focuses on assessing the geopolitical situation in Europe, which, in the opinion of the authors, has turned into a multipolar system: "Although Europeans welcomed the birth of a multipolar world, they almost did not notice that in parallel is formed and a multipolar Europe, which is characterized by an increasing competition between the main forces of the continent - the EU, Russia and Turkey - for influence in the newly established States, formed after the collapse of the Soviet Union and Yugoslavia" (Krastev \& Leonard, 2017). In 2008, the European Council issued a new document entitled "Ensuring Security in a Changing World". The principles of European security remained virtually unchanged: a stronger, more united and capable Europe, participation in the life of its neighbors, as well as cooperation with partners, to which the other members of the BRICS - Brazil and South Africa - were added.

\section{Conclusion}

Given the events of recent years, security issues in Europe are of particular relevance. European countries are building national security systems based on own national interests, vision and analysis of political processes taking place in the world, as well as political experience and the professional competence of political elites.

Many countries in Europe are members of the North Atlantic Treaty Organization (NATO). The Euro-Atlantic Alliance is a significant component of the national security systems of the dominant number of countries in Central and Eastern Europe. Considering the dynamism of the integral processes in Europe, the countries with the greatest security load are among those countries.

National security systems in Europe differ in the role of national security actors. The approaches of the leading European countries differ in terms of the geography of national security interests. The conceptual documents of the European countries identify the role of intelligence as a strategic tool in preventing threats to national security. 


\section{References}

Balzacq, T. (2010). Securitization Theory: How Security Problems Emerge and Dissolve. Abingdon: Routledge. https://doi. org/10.4324/9780203868508

Bigo, D. (2000). When Two Become One: Internal and external securitisation in Europe. In M. Kelstrup, \& M. Williams, International Relations Theory and the Politics of European Integration: Power, Security, and Community (pp. 171-204). London and New York: Routledge. ISBN: 978-0415214162

Bigo, D. (2001). The Mobius Ribbon of Internal and External Security(ies). In M. Albert, D. Jacobsen, \& Y. Lapid, Identities, Borders, Orders -Rethinking International Relations Theory (pp. 91-136). London: University of Minnesota Press. ISBN: 978-0-8166-3607-5

Bigo, D., \& Tsoukala, A. (2017, August 26). Understanding (In)Security. Retrieved from didierbigo.com: http://didierbigo.com/ wp-content/uploads/2016/03/UnderstandingInsecurity.pdf

Biskop, S. (2010). Handbook on CSDP: The Common Security and Defence Policy of the European Union. Vienna: Directorate for Security Policy of the Federal Ministry of Defence and Sports of the Republic of Austria. :https://doi.org/10.2855/414003

Bonditti, P., Bigo, D., \& Gros, F. (2017). Foucault and the Modern International: Silences and Legacies for the Study of World Politics. Berlin: Springer. ISBN: 978-1-137-56158-9

Booth, K. (2007). Theory of World Security. Cambridge: Cambridge University Press. https://doi.org/10.1017/CBO9780511840210

Burgess, J. (2010). The Ethical Subject of Security: Geopolitical Reason and the Threat Against Europe. Abingdon: Routledge. ISBN: 9780415499828

Buzan, B., Waever, O., \& Wilde, J. (1998). Security: A New Framework for Analysis. Boulder, CO: Lynne Rienner Publishers. ISBN: $1-55587-603-\mathrm{X}$

Coelmont, J. (2017, August 26). A European Global Security Strategy: Offering Seven-League Boots to Become a Global Actor. Retrieved from aei.pitt.edu: http://aei.pitt.edu/43288/1/SPB45.pdf

EUR-LEX. (2012, October 26). the Treaty on European Union and the Treaty on the Functioning of the European Union. Retrieved from eur-lex.europa.eu: http://eur-lex.europa.eu/legal-content/en/TXT/?uri=CELEX\%3A12012M\%2FTXT

Fabuš, M. 2017. Current development of business environment in Slovakia and Czech Republic, Entrepreneurship and Sustainability Issues 5(1): 127-137. https://doi.org/10.9770/jesi.2017.5.1(10)

Gruszczak, A. (2016). Intelligence Security in the European Union: Building a Strategic Intelligence Community. Berlin: Springer. https://doi.org/10.1057/978-1-137-45512-3

Hokovský, R. (2016). The Concept of Border Security in the Schengen Area. Central European Journal of International and Security Studies, 10(2), 72-93. Retrieved from: https://static.cejiss.org/data/uploaded/1474975444714058/4\%20article.pdf

Hollis, S. (2010). The necessity of protection: Transgovernmental networks and EU security governance. Cooperation and Conflict, 45(3), 312-330. https://doi.org/10.1177/0010836710378071

Jones, R. (1999). Security, Strategy, and Critical Theory. Boulder, CO: Lynne Rienner Publishers. Retrieved from: https://www.researchgate.net/profile/Richard_Jones36/publication/265023798_Security_Strategy_and_Critical_Theory/links/54f43f870cf299c8d9e66640/ Security-Strategy-and-Critical-Theory.pdf

Keohane, J., \& Nye, R. (1971). Transnational Relations and World Politics: An Introduction. Transnational Relations and World Politics, 25(3), 329-349. Retrieved from: http://www.jstor.org/stable/2706043

Kirchner, E., \& Sperling, J. (2009). EU Security Governance. JCMS: Journal of Common Market Studies, 47, 677-678. https://oi. org/10.1111/j.1468-5965.2009.02000_3.x

Kirchner, E., Fanoulis, E., \& Dorussen, H. (2015). Civil security in the EU: national persistence versus EU ambitions? European Security, 24(2), 287-303. https://doi.org/10.1080/09662839.2014.968133

Kirshner, J. (2013). Globalization and National Security. London: Routledge. ISBN: 978-0415955119

Koenig, N. (2016). EU Security Policy and Crisis Management: A Quest for Coherence. New York: Routledge. ISBN: 978-1138961340

Kordík, M.; Kurilovská, L. 2017. Protection of the national financial system from the money laundering and terrorism financing, Entre- 
preneurship and Sustainability Issues 5(2): 243-262. https://doi.org/10.9770/jesi.2017.5.2(7)

Krastev, I., \& Leonard, M. (2017, August 26). The Spectre of a Multipolar Europe. The Illusion of Order and the Rise of Multipolar Europe. European Council on Foreign Relations. Retrieved from www.ecfr.eu: http://www.ecfr.eu/page/-/Multipolar\%20Europe\%20 English.pdf

Kunitsyna, N.; Britchenko, I.; Kunitsyn, I. 2018. Reputational risks, value of losses and financial sustainability of commercial banks, Entrepreneurship and Sustainability Issues 5(4): 943-955. https://doi.org/10.9770/jesi.2018.5.4(17)

Kuril, J. 2018. Public administration for safe and secure environment: case of Slovak Republic, Entrepreneurship and Sustainability Issues 5(3): 493-501. https://doi.org/10.9770/jesi.2018.5.3(6)

Lavenex, S., \& Wagner, W. (2007). Which European Public Order? Sources of Imbalance in the European Area of Freedom, Security and Justice. European Security, 16(3), 225 - 243. https://doi.org/10.1080/09662830701753972

Lavenex, S., \& Wichmann, N. (2013). Political Order. In S. Wolff, N. Wichmann, \& G. Mounier, The External Dimension of Justice and Home Affairs: A Different Security Agenda for the European Union? (pp. 81-86). Abingdon: Routledge. https://doi. org/10.1080/07036330802503817

Leese, M., \& Wittendorp, S. (2017). Security/Mobility : Politics of Movement. Manchester: Manchester University Press. ISBN: 9781526107459

Lietuvnike, M. M.; Vasilis Vasiliauskas, A.; Vasilienė-Vasiliauskienė, V.; Sabaitytė, J. 2018. Peculiarities of illegal immigrant's intrusions into road freight transport units in the France - UK corridor, Entrepreneurship and Sustainability Issues 5(3): 634-647. https://doi. org/10.9770/jesi.2018.5.3(16)

Limba, T.; Agafonov, K.; Paukštè, L.; Damkus, M.; Plèta, T. 2017. Peculiarities of cyber security management in the process of internet voting implementation, Entrepreneurship and Sustainability Issues 5(2): 368-402. https://doi.org/10.9770/jesi.2017.5.2(15)

Lutterbeck, D. (2005). Blurring the Dividing Line: The Convergence of Internal and External Security in Western Europe. European Security, 14(2), 231-253. https://doi.org/10.1080/09662830500336193

Matvejevs, A. 2018. Effective crime control as guarantor of public security, Journal of Security and Sustainability Issues 7(3): 417-426. https://doi.org/10.9770/jssi.2018.7.3(4)

Mosser, M. (2014). Embracing "embedded security": the OSCE's understated but significant role in the European securityarchitecture. European Security, 24(4), 579-599. https://doi.org/10.1080/09662839.2015.1054376

Njaramba, J.; Chigeza, P.; Whitehouse, H. 2018. Barriers and challenges experienced by migrant African women entrepreneurs in North Queensland, Australia, Entrepreneurship and Sustainability Issues 5(4): 1054-1068. https://doi.org/10.9770/jesi.2018.5.4(25)

Nolte, E., MacLehose, L., \& McKee, M. (2004). Health, Policy and European Union Enlargement. n.a.: Open University Press. Retrieved from: http://www.euro.who.int/_data/assets/pdf_file/0004/98392/E82999.pdf

Ohotina, A.; Lavrinenko, O.; Ignatjeva, S.; Lonska, J. 2018. Socio-economic security as a determinant of regional differences in the investment climate in the region, Journal of Security and Sustainability Issues 7(3): 427-438. https://doi.org/10.9770/jssi.2018.7.3(5)

Petrenko, E.; Iskakov, N.; Metsyk, O.; Khassanova, T. 2017. Ecosystem of entrepreneurship: risks related to loss of trust in stability of economic environment in Kazakhstan, Entrepreneurship and Sustainability Issues5(1): 105-115. https://doi.org/10.9770/jesi.2017.5.1(8)

Plèta, T.; Karasov, S.; Jakštas, T. 2018. The means to secure critical energy infrastructure in the context of hybrib warfare: the case of Ukraine, Journal of Security and Sustainability Issues 7(3): 567-578. https://doi.org/10.9770/jssi.2018.7.3(16)

Ritzer, G. (2017, August 26). The Weberian Theory of Rationalization and the McDonaldization of Contemporary Society. Retrieved from pdfs.semanticscholar.org: https://pdfs.semanticscholar.org/3db2/43f52c96cdcfd98f022349b35a9a14ffbe61.pdf

Shvetsova, O. A.; Rodionova, E. A.; Epstein, M. Z. 2018. Evaluation of investment projects under uncertainty: multi-criteria approach using interval data, Entrepreneurship and Sustainability Issues 5(4): 914-928. https://doi.org/10.9770/jesi.2018.5.4(15)

Singh, R. P. (2017, August 26). Critical Theory of Juergen Habermas: A Critique of Enlightment Rationality. Retrieved from www. unipune.ac.in: http://www.unipune.ac.in/snc/cssh/ipq/english/IPQ/26-30\%20volumes/26-3/26-3-6.pdf

Šišulák, S. 2017. Userfocus - tool for criminality control of social networks at both the local and international level, Entrepreneurship and Sustainability Issues 5(2): 297-314. https://doi.org/10.9770/jesi.2017.5.2(10)

Slaughter, A.-M. (1997). The real new world order. Foreign Affairs, 183-197. Retrieved from: https://www.foreignaffairs.com/arti- 
cles/1997-09-01/real-new-world-order

Standler, C. (2014). Mapping out the institutional geography of external security in the EU. European Security, 24(3), 402-419. https:// doi.org/10.1080/09662839.2015.1028187

The General Secretariat of the Council of Europe. (2017, August 26). Internal Security Strategy for teh European Union: Towards a European Security Model. Retrieved from www.consilium.europa.eu: https://www.consilium.europa.eu/uedocs/cms_data/librairie/ PDF/QC3010313ENC.pdf

Todorov, G. N.; Kalinina, A. V.; Rybakova, A. I. 2018. Impact of labour migration on entrepreneurship ecosystem: case of Eurasian Economic Union, Entrepreneurship and Sustainability Issues 5(4): 992-1007. https://doi.org/10.9770/jesi.2018.5.4(20)

Trybus, M. (2014). Buying Defence and Security in Europe. Cambridge: Cambridge University Press. https://doi.org/10.1017/ CBO9780511751462

Tvaronavičienè, M. 2018. Toward efficient policymaking: forecasts of vulnerability to external global threats, Journal of Security and Sustainability Issues 7(3): 591-600. https://doi.org/10.9770/jssi.2018.7.3(18)

Vaughan-Williams, N. (2008). Borders, Territory, Law. International Political Sociology, 4(2), 322-338. https://doi.org/10.1111/j.17495687.2008.00054.x

Wark, M. (2005). Securing Security. Kritikos: International and interdisciplinary journal of postmodern cultural sound, text and image, 2. ISBN: $1552-5112$

Zahars, V.; Stivrenieks, M. 2018. Security, surveillance and re-socialization aspects in center for drug addicts of Olaine city prison in Latvia, Journal of Security and Sustainability Issues 7(4): 643-656. https://doi.org/10.9770/jssi.2018.7.4(3) 